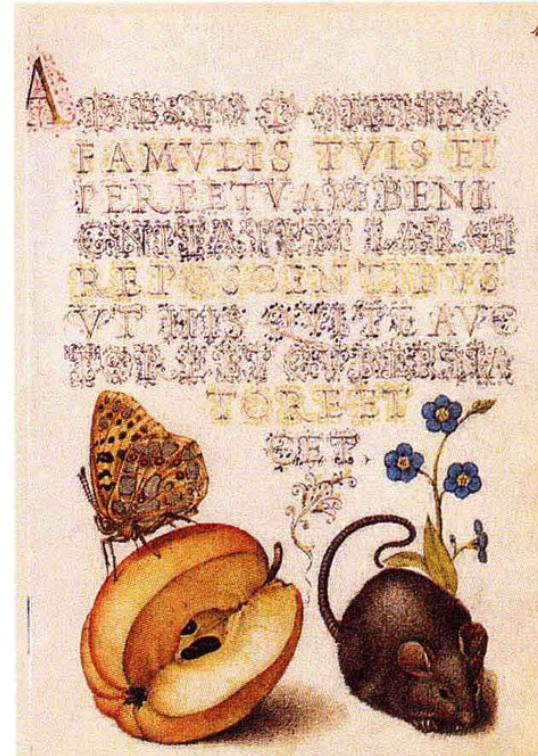

\title{
Renaissance view of nature in miniature
}

One of the most precious books of the European Renaissance, The Model Book of Calligraphy, was created at the court of the Holy Roman Emperors in the latter part of the sixteenth century. The scripts were the work of the

A chapter contributed by the botanist James I. Reveal on the identification of plants in the pre-Linnean botanical literature gives an excellent account of what was known in ancient and mediaeval times, and what the difficulties can be in relating early plant descriptions to those of today. One of the great influences of classical times - and the following 16 centuries was Pedanios Dioscorides (born about $\mathrm{AD}$ 40 ), the Cilician Greek physician to the armies of Nero, who wrote De Materia Medica. Dioscorides provided information on some 600 plant species along with their pharmaceutical uses. These were added to by the important Islamic writer Avicenna who wrote the Canon of Medicine, which was eventually translated from Arabic into Latin in the twelfth century and became a much used companion to Dioscorides' work. Such well known and translated sources form an obvious starting point in a quest for ancient medicinal remedies but there are many other less well known sources to be searched out.

So far as medical writings of the Middle Ages and Renaissance are concerned, many are available for study, if at some inconvenience to the modern reader. A very useful and scholarly account is given in a chapter by Anne Van Arsdall.

Elizabeth R. Macgill discusses a primary Renaissance source, This Booke of Soverigne Medicines by John Feckenham, Abbot of Westminster, which was probably used by the Benedictine Order around 1570. Macgill quotes many plant remedies for various con-

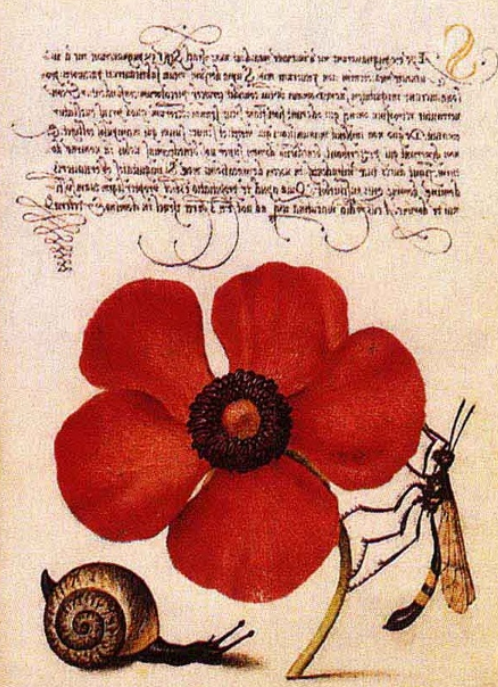

imperial secretary Georg Bocskay. After Bocskay's death, Emperor Rudolf II commissioned the illuminator Joris Hoefnagel to illustrate the calligrapher's work with meticulous miniatures of plants and animals.

ditions and, if rather quaint, they are more or less intelligible to the modern reader, being in the English of Shakespeare.

Here is a sample: "A medicine to purge a bladder of him that cannot pysse. Take ffennell the leaves and the rootes, Allysanders parsley, the leaves \& the roote of hartstong, mayden heare, and seeth them in white wine, and give it the patient to drink, and it shall purge the bladder in a short time."

The random screening of 114,000 terrestrial plant extracts from 35,000 species by the US National Cancer Institute gave only two significant compounds - taxol and camptothecin - so the assistance of clues to narrow the choice of plants for test is welcome. Some of the really effective plant remedies of our forebears have stood the test of time and are already with us today, such as colchicine, morphine, salicylates and atropine. So the search has to be for overlooked effective botanical remedies, perhaps lost among the charlatanism, quackery and astrological beliefs of earlier days.

Such a search seems worthwhile and this book will be extremely valuable to the team best fitted for the task - the scholar with appropriate linguistic and historical qualifications working alongside the scientist, probably a pharmacist. Even with a really good lead, the long hard road to a usable modern drug is only just beginning, and may well end in failure.

Leslie Crombie is in the Department of

Chemistry, University of Nottingham,

Nottingham NG7 2RD, UK.

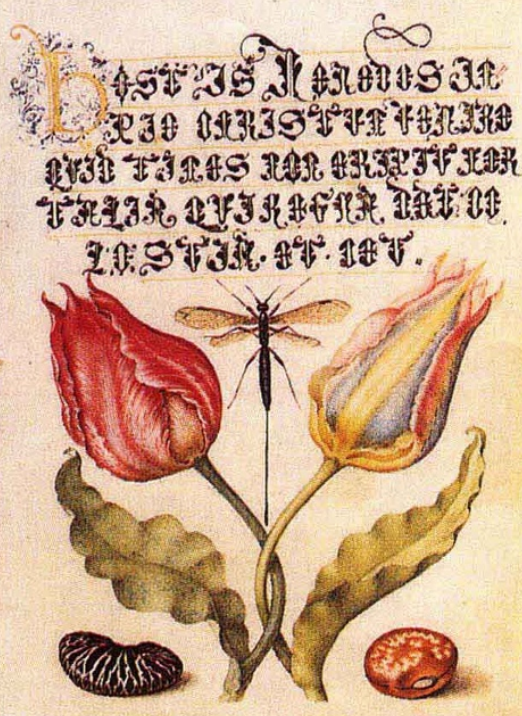

A set of pages from the book is reproduced in Nature Illuminated: Flora and Fauna from the Court of the Emperor Rudolf II by Lee Hendrix and Thea Vignau-Wilberg (Thames and Hudson, £7.95).

\section{New journals}

This year, Nature's annual new journals review supplement will appear in the issue of 11 September. Publishers and learned societies are invited to submit journals for review, as well as details of any eligible electronic journals, taking note of the following criteria:

* Journals that first appeared during or after June 1995 and issued at least four separate numbers by the end of May 1997 will be considered. - Journals covering any aspect of science are eligible, although those dealing with clinical medicine and pure mathematics are excluded, as are publications of abstracts.

- Frequency of publication must be at least three times a year. The main language used must be English. Translation journals in English are, of course, eligible.

- Deadline for submission is 6 June. When submitting journals for review, please send at least four different issues (the first, the most recent and any two others) of each title, together with full details of subscription rates.

For further information please contact Peter Tallack, Book Reviews Editor, Nature, Macmillan Magazines, Porters South, Crinan Street,

London N1 9XW, UK.

Tel: +44 (0)171 8434567 .

e-mail:p.tallack@nature.com 